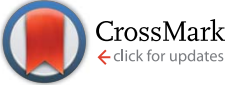

Cite this: RSC Adv., 2016, 6, 3074

\title{
Field-induced slow relaxation of magnetization in dinuclear and trinuclear $\mathrm{Co}^{\mathrm{III}} \ldots \mathrm{Mn}^{\mathrm{III}}$ complexes $\dagger$
}

\author{
Ivan Nemec, Radovan Herchel, Zdeněk Trávníček* and Tomáš Šilha
}

Two new dinuclear, [Co(3EtO-L5)( $\mu-\mathrm{CN}) \mathrm{Mn}(\mathrm{L} 4 \mathrm{a}) \mathrm{Cl}]$ (1) and [Co(3EtO-L5)( $\mu-\mathrm{CN}) \mathrm{Mn}(\mathrm{L} 4 \mathrm{a}) \mathrm{Br}](2)$, and two trinuclear $\left[\{\mathrm{Co}(3 \mathrm{EtO}-\mathrm{L} 5)(\mu-\mathrm{CN})\}_{2} \mathrm{Mn}(\mathrm{L} 4 \mathrm{a})\right] \mathbf{l}$ (3) and $\left[\{\mathrm{Co}(3 \mathrm{EtO}-\mathrm{L} 5)(\mu-\mathrm{CN})\}_{2} \mathrm{Mn}(\mathrm{L} 4 \mathrm{a})\right]\left(\mathrm{NO}_{3}\right)$ (4) complexes were prepared and thoroughly characterized ( $\mathrm{H}_{2} 3 \mathrm{EtO}-\mathrm{L} 5=\mathrm{N}, \mathrm{N}^{\prime}$-bis(3-ethoxy-2-hydroxybenzylidene)1,6-diamino-3-azahexane, $\mathrm{L}_{4} \mathrm{a}^{2-}=\mathrm{N}, \mathrm{N}^{\prime}$-ethane-bis(salicylideneiminate)dianion). The crystal structures were determined for all four compounds, while the static and dynamic magnetic properties were studied only for compounds $1-3$. It has been revealed by simultaneous fitting of temperature and field dependent magnetic data and by using the spin Hamiltonian formalism involving the axial anisotropy term that the manganese(II) atoms possess relatively large and negative axial magnetic anisotropy in 1-3, with $D=-3.9(2) \mathrm{cm}^{-1}$ in $1,-4.9(2) \mathrm{cm}^{-1}$ in 2 , and $-4.1(1) \mathrm{cm}^{-1}$ in 3 . These results were supported by $a b$ initio CASSCF calculations which were in good agreement with the experimental ones, however, a small rhombicity was calculated contrary to the experimental evaluations: $D_{\text {calc }}\left(E_{\text {calc }} / D_{\text {calc }}\right)=-3.2 \mathrm{~cm}^{-1}(0.04)$ in $1,-3.0 \mathrm{~cm}^{-1}(0.03)$ in 2 , and $-3.6 \mathrm{~cm}^{-1}(0.04)$ in 3 . The measurements of dynamic magnetic data confirmed that compounds $1-3$ represent a new type of $\mathrm{Mn}($ III) field-induced single-ion magnet. The peak maxima of the frequency dependent out-phase susceptibility were below the lowest accessible temperature in all the three cases (i.e. below $1.9 \mathrm{~K}$ ) and this prevented us from the construction of the Argand diagram. Nevertheless, the approximate procedure for extracting the spin-reversal barrier $\left(U_{\text {eff }}\right)$ and relaxation time $\left(\tau_{0}\right)$ was used, and the values of $U_{\text {eff }}$ ranging from 11 to $20 \mathrm{~K}$ and $t_{0}$ from 0.1 to $19 \times$ $10^{-7} \mathrm{~s}$ were obtained.

Received 12th November 2015 Accepted 18th December 2015

DOI: $10.1039 /$ c5ra23922b

www.rsc.org/advances

\section{Introduction}

Compounds exhibiting slow relaxation of magnetization (SRM), so called single-molecule magnets (SMMs), attract great attention in the field of molecule-based magnetic materials research. Their potential utilization in molecular spintronics and information storage devices has been intensively studied. ${ }^{1}$ SMMs can behave as molecular nanomagnets possessing distinct magnetic states separated by an energy barrier for spin reversal, while the height of this barrier is controlled by magnetic anisotropy of paramagnetic centre/centres of a molecule. Therefore, the rational design of such materials consists mostly of tuning of uniaxial magnetic anisotropy to large negative values (described by the zero-field splitting parameter $D$ ); however, there are several examples of mononuclear compounds exhibiting SRM and having positive $D$ values. $^{2}$

The $\mathrm{Mn}^{\mathrm{III}}$ atom in a hexacoordinate environment is due to its electronic structure in the high-spin state (HS, $S=2, t_{2 \mathrm{~g}}^{3} \mathrm{e}_{\mathrm{g}}^{1},{ }^{5} E$

Regional Centre of Advanced Technologies and Materials \& Department of Inorganic Chemistry, Faculty of Science, Palacký University, 17. listopadu 12, 77146 Olomouc, Czech Republic. E-mail: zdenek.travnicek@upol.cz; Fax: +420 585634954 $\dagger$ Electronic supplementary information (ESI) available. CCDC 1434760-1434763. For ESI and crystallographic data in CIF or other electronic format see DOI: $10.1039 / \mathrm{c} 5 \mathrm{ra} 23922 \mathrm{~b}$ ground spectroscopic term) subject of Jahn-Teller distortion. ${ }^{3}$ As a result, a significant prolongation of two opposite chromophore bond lengths and thus formation of an axially elongated tetragonal bipyramidal coordination polyhedron is observed. This geometry is favourable for the occurrence of relatively large and negative uniaxial magnetic anisotropy, as it was observed on numerous examples previously. ${ }^{4}$ Therefore, paramagnetic compounds involving the $\mathrm{Mn}^{\mathrm{III}}$ atoms are the promising objects for the preparation and study of compounds exhibiting SRM. Especially, the $\mathrm{Mn}^{\mathrm{III}}$ compounds involving tetradentate salen-like Schiff base ligands $\left[\mathrm{L}^{2-}\right.$ stands for a general abbreviation of a tetradentate salen-like ligand, salen $^{2-}=N, N^{\prime}$-ethane-bis(salicylideneiminate) dianion, further

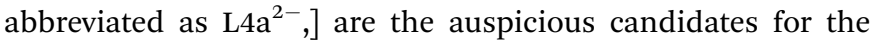
preparation of magnetically interesting compounds. This is due to the ability of $\mathrm{L}^{2-}$ compounds to act as ligands forming the equatorial plane in complexes with axially elongated coordination geometries with expectable negative magnetic anisotropy. Previous reports on the observation of SRM in $\left[\mathrm{Mn}^{\mathrm{III}}(\mathrm{L} 4)\right]$-type compounds dealt with three basic structural types, i.e. polynuclear compounds (a) involving the $\left[\mathrm{Mn}^{\mathrm{III}}(\mathrm{L} 4)\right]^{+}$subunit coordinated by bridging ligands or complexes, ${ }^{5}$ (b) involving the phenoxo bridged dimeric subunits $\left[\left\{\mathrm{Mn}^{\mathrm{III}}(\mathrm{L} 4)\right\}_{2}\right]^{2+}$ which are further coordinated in apical positions by ligands/complexes, ${ }^{6}$ 
and (c) involving the $\left[\mathrm{Mn}^{\mathrm{III}}(\mathrm{L} 4)(\mathrm{Solv})\right]^{+}$subunits $(\mathrm{Solv}=$ water or alcohol molecule) coordinated by cyanidometallates. ${ }^{7}$ In the latter group, the very first example of the $\mathrm{Mn}^{\mathrm{III}} \mathrm{SMM}$ with only one paramagnetic centre (so called Single-Ion Magnet, SIM) has been reported recently. The heterobimetallic $\mathrm{Co}^{\mathrm{III}}-\mathrm{CN}-\mathrm{Mn}^{\mathrm{III}}$ compound shows relatively small negative $D=-3.3 \mathrm{~cm}^{-1}$ and SRM occurs below $3 \mathrm{~K}^{\mathbf{8}}$

Previously, we reported on heterobimetallic $\left[\mathrm{Co}^{\mathrm{III}}(3 \mathrm{EtO}-\mathrm{L} 5)-\right.$ $\left.(\mu-\mathrm{CN}) \mathrm{Fe}^{\mathrm{III}}(\mathrm{L} 4 \mathrm{a}) \mathrm{Cl}\right]$ compound (further abbreviated as $\mathrm{CoFeCl}$, where $\mathrm{H}_{2} 3 \mathrm{EtO}-\mathrm{L} 5=N, N^{\prime}$-bis(3-ethoxy-2-hydroxybenzylidene)-1,6diamino-3-azahexane), having relatively large magnetic anisotropy $\left(D=+1.47 \mathrm{~cm}^{-1}\right)$ on a usually very isotropic $\mathrm{Fe}^{\mathrm{III}}$ atom. This was most probably caused by a rather long $\mathrm{N}_{\mathrm{CN}}-\mathrm{Fe}-\mathrm{Cl}$ axial formed by bond lengths $\mathrm{Fe}-\mathrm{N}_{\mathrm{CN}}=2.236(2)$ and $\mathrm{Fe}-\mathrm{Cl}=$ $2.4075(7) \AA\left(\mathrm{N}_{\mathrm{CN}}=\right.$ the cyanido nitrogen atom). ${ }^{9}$ Inspired by these findings we attempted to prepare the $\mathrm{Mn}^{\mathrm{III}}$ analogues of the aforementioned compounds, which should possess large uniaxial magnetic anisotropy accentuated by the expected axially elongated tetragonal bipyramidal coordination polyhedron of the $\mathrm{Mn}^{\mathrm{III}}$ atom. Furthermore, in order to analyse the influence of the halido ligand exchange on magnetic properties, we tried to prepare a series of CoMnX compounds (with $\mathrm{X}=\mathrm{F}^{-}$, $\left.\mathrm{Cl}^{-}, \mathrm{Br}^{-}, \mathrm{I}^{-}\right)$. However, we were able to prepare only two isostructural compounds with the formulas $[\mathrm{Co}(3 \mathrm{EtO}-\mathrm{L} 5)(\mu-\mathrm{CN})$ $\mathrm{Mn}(\mathrm{L} 4 \mathrm{a}) \mathrm{Cl}$ ] (1) and [Co(3EtO-L5)( $\mu-\mathrm{CN}) \mathrm{Mn}(\mathrm{L} 4 \mathrm{a}) \mathrm{Br}$ ] (2). The other syntheses involving iodide and fluoride anions resulted in $\left[\{\mathrm{Co}(3 \mathrm{EtO}-\mathrm{L} 5)(\mu-\mathrm{CN})\}_{2}\{\mathrm{Mn}(\mathrm{L} 4 \mathrm{a})] \mathrm{I}(3)\right.$ and $\left[\{\mathrm{Co}(3 \mathrm{EtO}-\mathrm{L} 5)(\mu-\mathrm{CN})\}_{2^{-}}\right.$ $\mathrm{Mn}(\mathrm{L} 4 \mathrm{a})]\left(\mathrm{NO}_{3}\right)(4)$. Herein, we report on the syntheses, crystal structures (1-4) and thorough investigations of magnetic properties of the compounds 1-3. While our main intention was to study influence of the different axial ligand fields (and different axial lengths) on magnetic anisotropy of the Mn(III) atom, the magnetic properties of $\mathbf{4}$ were not studied due to the structural similarity with compound 3 .

\section{Results}

\section{Synthesis}

Compounds 1, 2 and 3 were prepared in a similar way. The $[\mathrm{Co}(3 \mathrm{EtO}-\mathrm{L} 5)(\mathrm{CN})]$ precursor complex ${ }^{9}$ was mixed with the corresponding $[\mathrm{Mn}(\mathrm{L} 4 \mathrm{a}) \mathrm{X}]$ or $\left[\mathrm{Mn}(\mathrm{L} 4 \mathrm{a})\left(\mathrm{H}_{2} \mathrm{O}\right)\right] \mathrm{I}$ compounds $(\mathrm{X}=$ $\mathrm{Cl}^{-}$in $1, \mathrm{Br}^{-}$in 2) in methanol and they were stirred under heating for 15 minutes. The solution was filtered to a beaker and left to cool down. Then, the beaker was sealed with aluminium foil and placed in a big flask with diethyl ether. Single crystals of high quality were obtained by slow diffusion of diethyl ether to the mother liquor. The products of the first two reactions were identified as [Co(3EtO-L5) $(\mu-\mathrm{CN}) \mathrm{Mn}(\mathrm{L} 4 \mathrm{a}) \mathrm{Cl}](\mathbf{1})$ and $[\mathrm{Co}(3 \mathrm{EtO}-\mathrm{L} 5)(\mu-\mathrm{CN}) \mathrm{Mn}(\mathrm{L} 4 \mathrm{a}) \mathrm{Br}]$ (2), while the described reaction resulted in an unexpected trinuclear product $\left[\{\mathrm{Co}(3 \mathrm{EtO}-\mathrm{L} 5)(\mu-\mathrm{CN})\}_{2}\{\mathrm{Mn}(\mathrm{L} 4 \mathrm{a})] \mathrm{I}(3\right.$, Scheme 1$)$ in the case of the iodido precursor complex. The attempts to synthesise the fluoride analogous of $\mathbf{1}$ and $\mathbf{2}$ were performed in two distinct ways. Firstly, the previously reported polymeric $[\mathrm{Mn}(\mathrm{L} 4 \mathrm{a})(\mu-\mathrm{F})]_{n}$ compound $^{10}$ was reacted with [Co(3EtO-L5)(CN)] in methanol. The length of heating and stirring varied from 15 minutes to 24 hours. However, the slow diffusion of diethyl ether led only to

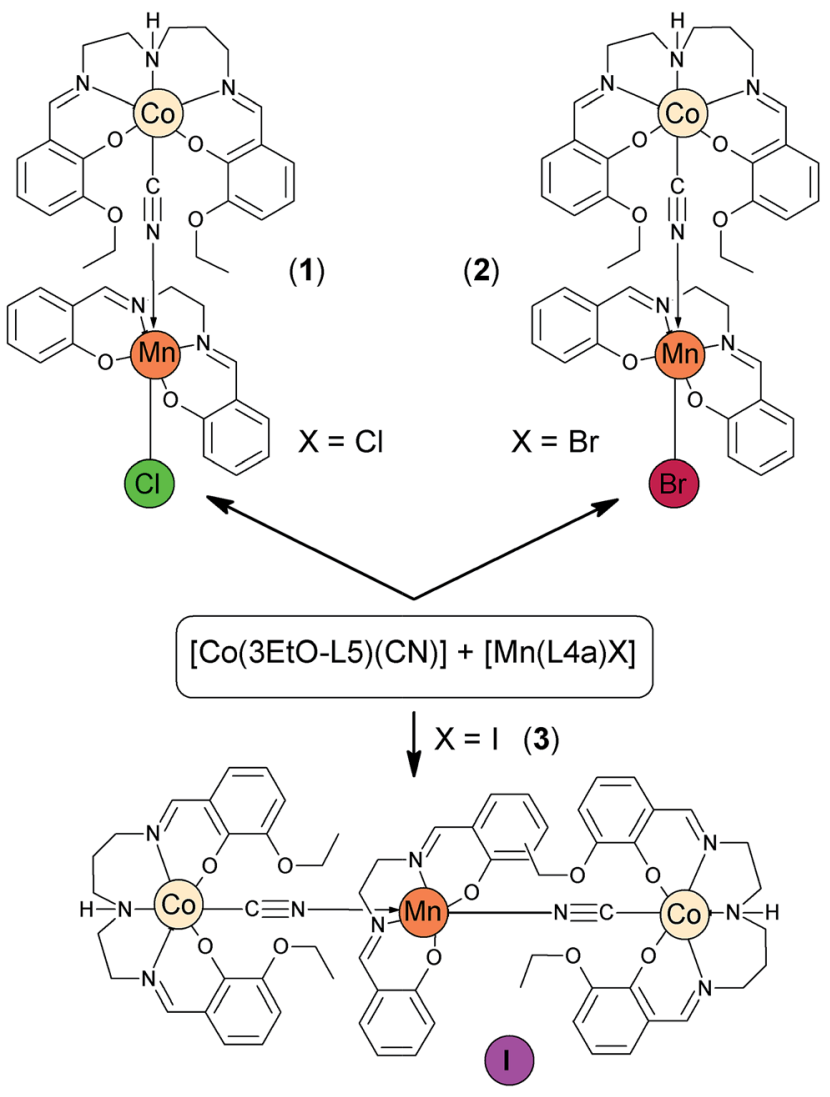

Scheme 1 Schematic representations of complexes 1-3 and their preparations. Note: the preparation of complex 4 is described in the text below.

crystallization of the precursor complexes in every case. Secondly, in order to avoid the formation of the $[\mathrm{Mn}(\mathrm{L} 4 \mathrm{a})(\mu-\mathrm{F})]_{n}$ polymer we used the $[\mathrm{Mn}(\mathrm{L} 4 \mathrm{a}) \mathrm{Cl}]$ precursor, which was subsequently reacted with $\mathrm{AgNO}_{3}(\mathrm{AgCl}$ was filtered off) in methanol. Then, the solution was mixed with the solid of [Co(3EtOL5)(CN)] and $\mathrm{NaF}$ was added after 10 min of stirring. After 30 minutes of heating and stirring, the reaction mixture was filtered, cooled down and left to undergo slow-diffusion of diethyl ether as in the previous cases. The resulting crystalline product did not contain fluoride anions and again as in the case of 3, it was a trinuclear complex with the formula of [ $\{\mathrm{Co}(3 \mathrm{EtO}-$ $\left.\mathrm{L} 5)(\mu-\mathrm{CN})\}_{2} \mathrm{Mn}(\mathrm{L} 4 \mathrm{a})\right]\left(\mathrm{NO}_{3}\right)(4)$.

\section{Crystal structure of 1 and 2}

The crystal structures of $\mathbf{1}$ and $\mathbf{2}$ are isostructural, crystallizing in monoclinic space group $P 2_{1}$ (Table 1 ) and they are also isostructural with the previously reported compound [Co(3EtO$\mathrm{L} 5)(\mu-\mathrm{CN}) \mathrm{Fe}(\mathrm{L} 4 \mathrm{a}) \mathrm{Cl}]{ }^{9}$

The crystal structures of $\mathbf{1}$ and 2 consist of dinuclear [Co(3EtO-L5) $(\mu-\mathrm{CN}) \mathrm{Mn}(\mathrm{L} 4 \mathrm{a}) \mathrm{X}](\mathrm{X}=\mathrm{Cl}$, and $\mathrm{Br}$, respectively) molecules in which the metal atoms are bridged by the cyanido ligand (Co-CN-Mn linkage, Fig. 1). The arrangement of the metal atoms and the bridging ligand is slightly bent with the Co-C-Mn angles equal to $163.6^{\circ}$ in $\mathbf{1}$ and $163.7^{\circ}$ in 2 . The $\mathrm{Co}^{\mathrm{III}}$ centre is coordinated by three nitrogen and two oxygen atoms 
Table 1 Crystal data and structure refinements for 1-4

\begin{tabular}{|c|c|c|c|c|}
\hline & 1 & 2 & 3 & 4 \\
\hline Formula & $\mathrm{C}_{40} \mathrm{H}_{43} \mathrm{~N}_{6} \mathrm{O}_{6} \mathrm{Cl}_{1} \mathrm{Co}_{1} \mathrm{Mn}_{1}$ & $\mathrm{C}_{40} \mathrm{H}_{43} \mathrm{~N}_{6} \mathrm{O}_{6} \mathrm{Br}_{1} \mathrm{Co}_{1} \mathrm{Mn}_{1}$ & $\mathrm{C}_{64} \mathrm{H}_{72} \mathrm{~N}_{10} \mathrm{O}_{10} \mathrm{I}_{1} \mathrm{Co}_{2} \mathrm{Mn}_{1}$ & $\mathrm{C}_{64} \mathrm{H}_{72} \mathrm{~N}_{10} \mathrm{O}_{10} \mathrm{Co}_{2} \mathrm{Mn}_{1}$ \\
\hline$M_{\mathrm{r}}$ & 853.12 & 897.58 & 1441.01 & 1314.14 \\
\hline$a / \AA$ & $8.5566(3)$ & $8.5862(3)$ & $12.0234(5)$ & $35.108(2)$ \\
\hline$b / \AA$ & $19.8560(7)$ & $19.6159(8)$ & $18.2991(9)$ & $9.1128(4)$ \\
\hline$c / \AA$ & $11.1842(3)$ & $11.3835(4)$ & $27.7995(9)$ & $23.8187(18)$ \\
\hline$Z$ & 2 & 2 & 4 & 4 \\
\hline$D_{\mathrm{c}} / \mathrm{g} \mathrm{cm}^{-3}$ & 1.516 & 1.583 & 1.569 & 1.417 \\
\hline$\mu / \mathrm{mm}^{-1}$ & 0.910 & 1.894 & 1.316 & 0.801 \\
\hline$F(000)$ & 884 & 920 & 2952 & 2739 \\
\hline Reflections collected/unique & $12300 / 6236$ & $12736 / 6070$ & $44514 / 10625$ & $22119 / 5246$ \\
\hline Data/restraints/parameters & $6236 / 1 / 481$ & $6070 / 1 / 499$ & $10625 / 2 / 804$ & $5246 / 2 / 378$ \\
\hline
\end{tabular}

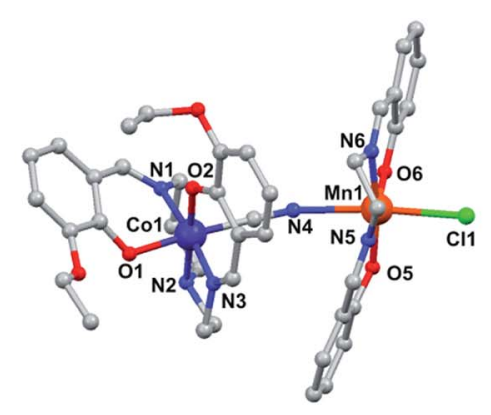

(a)

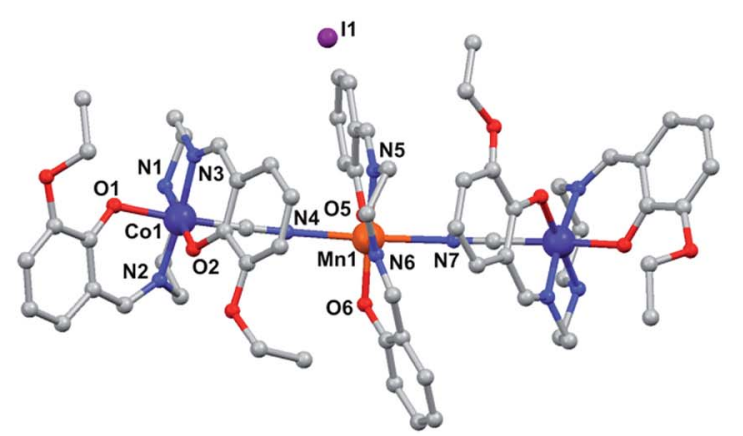

(c)

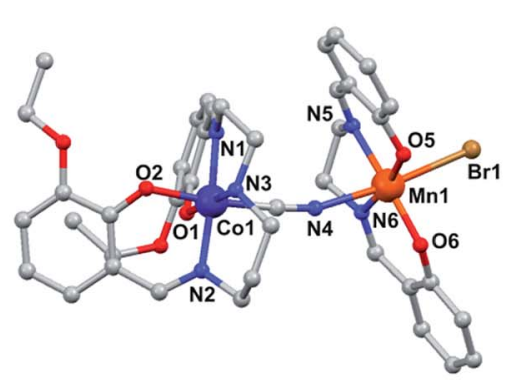

(b)

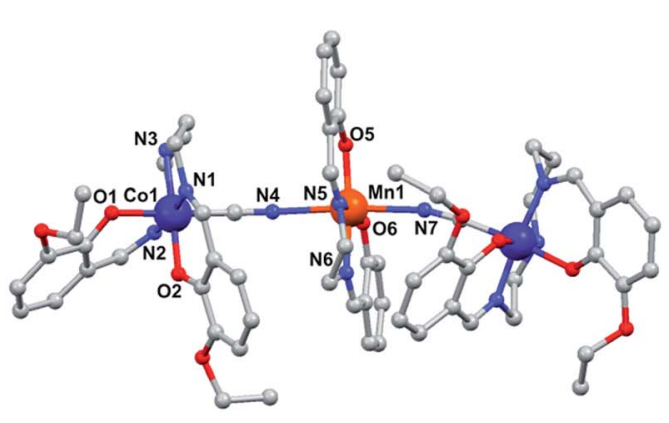

(d)

Fig. 1 Molecular structures of (a) [Co(3EtO-L5)( $\mu-\mathrm{CN}) \mathrm{Mn}(\mathrm{L} 4 \mathrm{a}) \mathrm{Cl}](1)$, (b) [Co(3EtO-L5)( $\mu-\mathrm{CN}) \mathrm{Mn}(\mathrm{L} 4 \mathrm{a}) \mathrm{Br}](2),(\mathrm{c})\left[\{\mathrm{Co}(3 \mathrm{EtO}-\mathrm{L} 5)(\mu-\mathrm{CN})\}_{2} \mathrm{Mn}(\mathrm{L} 4 \mathrm{a})\right] \mathbf{l}$ (3), (d) $\left[\{\mathrm{Co}(3 \mathrm{EtO}-\mathrm{L} 5)(\mu-\mathrm{CN})\}_{2} \mathrm{Mn}(\mathrm{L} 4 \mathrm{a})\right]\left(\mathrm{NO}_{3}\right)$ (4). Selected bond lengths (in $\AA$ ): $\mathrm{Mn}(1)-\mathrm{N}(5)=1.991(3), \mathrm{Mn}(1)-\mathrm{N}(6)=1.999(3), \mathrm{Mn}(1)-\mathrm{N}(4)=$ 2.380(3), $\mathrm{Mn}(1)-\mathrm{O}(5)=1.881(3), \mathrm{Mn}(1)-\mathrm{O}(6)=1.887(3), \mathrm{Mn}(1)-\mathrm{Cl}(1)=2.550(1), \mathrm{Co}(1)-\mathrm{N}(1)=1.926(3), \mathrm{Co}(1)-\mathrm{N}(2)=1.893(3), \mathrm{Co}(1)-\mathrm{N}(3)=$ 1.962(3), $\mathrm{Co}(1)-\mathrm{O}(1)=1.902(3), \mathrm{Co}(1)-\mathrm{O}(2)=1.908(2)$ for $1, \mathrm{Mn}(1)-\mathrm{N}(5)=1.992(4), \mathrm{Mn}(1)-\mathrm{N}(6)=1.989(4), \mathrm{Mn}(1)-\mathrm{N}(4)=2.325(4), \mathrm{Mn}(1)-\mathrm{O}(5)=$ 1.877(4), $\mathrm{Mn}(1)-\mathrm{O}(6)=1.884(4), \mathrm{Mn}(1)-\mathrm{Br}(1)=2.7394(8), \mathrm{Co}(1)-\mathrm{N}(1)=1.925(4), \mathrm{Co}(1)-\mathrm{N}(2)=1.889(4), \mathrm{Co}(1)-\mathrm{N}(3)=1.959(4), \mathrm{Co}(1)-\mathrm{O}(1)=$ 1.900(4), $\mathrm{Co}(1)-\mathrm{O}(2)=1.908(4)$ for $2, \mathrm{Mn}(1)-\mathrm{N}(5)=1.994(4), M n(1)-N(6)=1.971(3), M n(1)-N(4)=2.283(3), M n(1)-N(7)=2.347(3), M n(1)-O(5)=$ 1.873(3), $\mathrm{Mn}(1)-\mathrm{O}(6)=1.888(3), \mathrm{Co}(1)-\mathrm{N}(1)=1.890(4), \mathrm{Co}(1)-\mathrm{N}(2)=1.920(3), \mathrm{Co}(1)-\mathrm{N}(3)=1.971(3), \mathrm{Co}(1)-\mathrm{O}(1)=1.900(3), \mathrm{Co}(1)-\mathrm{O}(2)=1.915(2)$ for 3 and $M n(1)-N(5)=1.978(2), M n(1)-N(6)=1.978(2), M n(1)-N(4)=2.316(2), M n(1)-N(7)=2.316(2), M n(1)-O(5)=1.890(4), M n(1)-O(6)=$ 1.890(4), $\mathrm{Co}(1)-\mathrm{N}(1)=1.926(2), \mathrm{Co}(1)-\mathrm{N}(2)=1.894(2), \mathrm{Co}(1)-\mathrm{N}(3)=1.971(2), \mathrm{Co}(1)-\mathrm{O}(1)=1.899(2), \mathrm{Co}(1)-\mathrm{O}(2)=1.920(2)$ for 4 . 
from the 3EtO-L $5^{2-}$ ligand. The sixth coordination site is occupied by the carbon atom from the bridging cyanido ligand. The chromophore bond lengths are typical for the low-spin (LS) state with the lengths ranging from 1.89 to $1.91 \AA$ for Co-C, from 1.91 to $1.96 \AA$ for Co-N, and from 1.90 to $1.91 \AA$ for $\mathrm{Co}-\mathrm{O}$ bonds (Table 2). The coordination polyhedrons of the $\mathrm{Co}^{\mathrm{III}}$ atoms can be described as slightly distorted octahedrons in both compounds. The $\mathrm{Mn}^{\mathrm{III}}$ central atoms are also hexacoordinate with four equatorial donor atoms $\left(\mathrm{N}_{2} \mathrm{O}_{2}\right)$ coming from the $\mathrm{L}_{4} \mathrm{a}^{2-}$ ligand. The axial ligands are represented by one cynido nitrogen $\left(\mathrm{N}_{\mathrm{CN}}\right)$ and one halogen atom, thus forming the $\left\{\mathrm{MnN}_{3} \mathrm{O}_{2} \mathrm{Cl}\right\}$ (1) and $\left\{\mathrm{MnN}_{3} \mathrm{O}_{2} \mathrm{Br}\right\}$ (2) chromophores. The bond lengths within the equatorial plane are significantly shorter than those in axial due to the Jahn-Teller effect on the $\mathrm{Mn}^{\text {III }}$ atoms. This can be documented by the comparison of the Mn-N bond lengths: the equatorial manganese-imino nitrogen ( $\mathrm{Mn}-$ $\mathrm{N}_{\mathrm{im}}$ ) bond lengths are much shorter (1.91-1.95 $\AA$ ) than the axial Mn- $\mathrm{N}_{\mathrm{CN}}$ bond lengths (2.380(3) in 1 and 2.325(4) $\AA$ in 2). The Jahn-Teller prolongation of the bond lengths along the axis of the $d_{z}$ orbitals is further accentuated by long Mn-X lengths (2.5498(10) in 1 and 2.7394(8) $\AA$ in 2). When comparing these values with the bond lengths in the previously reported $\mathrm{CoFeCl}$ compound, the Jahn-Teller effect in the $\mathrm{Mn}^{\text {III }}$ compounds is even more apparent: $d\left(\mathrm{Fe}-\mathrm{N}_{\mathrm{CN}}\right)=2.236(2) \AA$ and $d(\mathrm{Fe}-\mathrm{Cl})=$ $2.4075(7) \AA .^{9}$

In the crystal structures of $\mathbf{1}$ and $\mathbf{2}$, the dinuclear molecules are connected through the $\mathrm{N}-\mathrm{H} \cdots \mathrm{X}$ hydrogen bonds, which arranges the individual molecules into one dimensional polymeric supramolecular chains, (Fig. 2) with $d(\mathrm{~N} \cdots \mathrm{Cl})=3.189(3)$ in 1 and $d(\mathrm{~N} \cdots \mathrm{Br})=3.306(4) \AA$ in 2 . The prolongation of the donor $\cdots$ acceptor distances upon substitution of the halido ligand reflects the decrease in the halide electronegativity along with growing atomic radius and polarizability.

\section{Crystal structures of 3 and 4}

The crystal structures of $\mathbf{3}$ and $\mathbf{4}$ are similar and they are composed of trinuclear $\left[\{\mathrm{Co}(3 \mathrm{EtO}-\mathrm{L} 5)(\mu-\mathrm{CN})\}_{2} \mathrm{Mn}(\mathrm{L} 4 \mathrm{a})\right]^{+}$cations which are charge balanced by iodide (in 3) or nitrate (in 4)

Table 2 Selected bond lengths for complexes 1-4 (in Å)

\begin{tabular}{lllll}
\hline & $\mathrm{Mn}^{-\mathrm{N}_{\mathrm{im}}}{ }^{a}$ & ${\mathrm{Mn}-\mathrm{O}^{a}}$ & $\mathrm{Mn}-\mathrm{N}_{\mathrm{CN}}$ & $\mathrm{Mn}-\mathrm{X}$ \\
\hline $\mathbf{1}$ & 1.995 & 1.884 & $2.380(3)$ & $2.550(1)$ \\
$\mathbf{2}$ & 1.991 & 1.881 & $2.325(4)$ & $2.7394(8)$ \\
$\mathbf{3}$ & 1.983 & 1.881 & $2.315^{a}$ & - \\
$\mathbf{4}$ & 1.978 & 1.892 & $2.316^{a}$ & - \\
\hline & $\mathrm{Co}^{a} \mathrm{~N}_{\mathrm{am}}$ & ${\mathrm{Co}-\mathrm{N}_{\mathrm{im}}}^{a}$ & ${\mathrm{Co}-\mathrm{O}^{a}}$ & $\mathrm{Co}-\mathrm{C}$ \\
\hline $\mathbf{1}$ & $1.962(3)$ & 1.910 & 1.905 & $1.907(3)$ \\
$\mathbf{2}$ & $1.959(4)$ & 1.907 & 1.904 & $1.893(5)$ \\
$\mathbf{3}$ & $1.948^{a}$ & $1.906^{b}$ & $1.911^{b}$ & $1.893^{a}$ \\
$\mathbf{4}$ & $1.971^{a}$ & $1.910^{b}$ & $1.910^{b}$ & $1.890^{a}$
\end{tabular}

${ }^{a}$ The average value calculated from two bond lengths. ${ }^{b}$ The average value calculated from four bond lengths. anions. The geometry of the trinuclear $\mathrm{Co}-\mathrm{CN}-\mathrm{Mn}-\mathrm{NC}-\mathrm{Co}$ fragment is bent with the Co-Mn-Co angle equal to $157.9^{\circ}$ in 3 and $159.2^{\circ}$ in 4 (Fig. 1). In 3, the whole trinuclear complex molecule is in the asymmetric unit, while in $\mathbf{4}$, a two-fold rotational axis goes through the manganese atom, and therefore only a half of the complex molecule is symmetrically independent. Similarly to 1 and 2 , the $\mathrm{Co}^{\mathrm{III}}$ coordination polyhedrons in 3 and $\mathbf{4}$ can be described as slightly distorted octahedrons with the $\left\{\mathrm{CoN}_{3} \mathrm{O}_{2} \mathrm{C}\right\}$ chromophores. The chromophore bond lengths correspond to the LS nature of the $\mathrm{Co}^{\mathrm{III}}$ centre with the lengths ranging from 1.89 to $1.90 \AA$ for $\mathrm{Co}-\mathrm{C}$, from 1.91 to $1.97 \AA$ for $\mathrm{Co}-$ $\mathrm{N}$, and from 1.90 to $1.91 \AA$ for Co-O bonds (Table 2). The $\mathrm{Mn}^{\mathrm{III}}$ atom is hexacoordinate with the $\left\{\mathrm{MnN}_{4} \mathrm{O}_{2}\right\}$ chromophores in both compounds. The bond lengths within the equatorial planes are very similar to those found in $\mathbf{1}$ and $\mathbf{2}\left(d\left(\mathrm{Mn}-\mathrm{N}_{\mathrm{im}}\right)=\right.$ 1.97-1.98 $\AA$, $d(\mathrm{Mn}-\mathrm{O})=1.88-1.89 \AA$, Table 2). The axial is formed by two $\mathrm{N}_{\mathrm{CN}}$ atoms from two coordinated [Co(3EtOL5)(CN)] fragments. Again, due to the Jahn-Teller effect long axial bonds are observed as follows: $d\left(\mathrm{Mn}-\mathrm{N}_{\mathrm{CN}}\right)=2.283(3)$, $2.347(3) \AA$ in 3 and $2.316(2)$ in 4 (two $\mathrm{Mn}-\mathrm{N}_{\mathrm{CN}}$ bonds are equivalent due to symmetry). It can be concluded that compounds 3 and 4 have a slightly shorter axial than compounds 1 and 2 (Table 2).

In the crystal structure of $\mathbf{3}$ the trinuclear complex molecules are assembled in 1D supramolecular chains through $\mathrm{N}-\mathrm{H} \cdots \mathrm{O}$ hydrogen bonding between the nitrogen atoms from the amine groups and oxygen atoms from the ethoxy groups; both located on the $[\mathrm{Co}(3 \mathrm{EtO}-\mathrm{L} 5)(\mathrm{CN})]^{-}$moieties of neighbouring trinuclear complex molecules. Each complex molecule is held by its inchain neighbour by two $\mathrm{N}-\mathrm{H} \cdots \mathrm{O}$ hydrogen bonds thus forming a synthon with the $\mathrm{R}_{2}{ }^{2}(14)$ ring topology (Fig. 2). ${ }^{11}$ The distances of these non-covalent contacts are rather long: $d(\mathrm{~N} \cdots$ O) $=3.307(4)$ and 3.168(4) Å.

The crystal structure of 4 consists of $\left[\{\mathrm{Co}(3 \mathrm{EtO}-\mathrm{L} 5)(\mu-\mathrm{CN})\}_{2}-\right.$ $\mathrm{Mn}(\mathrm{L} 4 \mathrm{a})]^{+}$molecules held together by $\mathrm{N}-\mathrm{H} \cdots \mathrm{O}$ hydrogen bonding between the nitrogen atom from the amine group and ethoxy group with the distance $d(\mathrm{~N} \cdots \mathrm{O})=3.173(4) \AA$ A. Packing of the $\left[\{\mathrm{Co}(3 \mathrm{EtO}-\mathrm{L} 5)(\mu-\mathrm{CN})\}_{2} \mathrm{Mn}(\mathrm{L} 4 \mathrm{a})\right]^{+}$molecules in the crystal structure of $\mathbf{4}$ is rather different from packing observed for $\mathbf{3}$; the complex molecules form a 2D layer structure in which each trinuclear complex interacts with four other complex molecules via four $\mathrm{N}-\mathrm{H} \cdots \mathrm{O}$ hydrogen bonds (Fig. 3). Due to the two fold rotational axis on the manganese(III) atom together with inversion centres located in between the molecules only one of these four hydrogen bonds is symmetrically independent. Its length is rather long again: $d(\mathrm{~N} \cdots \mathrm{O})=3.173(4) \AA$ A.

\section{Static magnetic properties}

The temperature and field dependent magnetic properties of compounds 1-3 were measured on a SQUID magnetometer and are depicted in Fig. 3. The room temperature value of the effective magnetic moment $\mu_{\text {eff }}$ is found in the range of 4.8-4.9 $\mu_{\mathrm{B}}$, which is close to the spin-only value for $S=2$ equal to 4.90 ( $\mathrm{g}$ $=2.0$ ). The $\mu_{\text {eff }}$ is almost constant down to $30 \mathrm{~K}$, and then decreases to the value $\approx 4 \mu_{\mathrm{B}}$ which may indicate zero-field splitting on the $\mathrm{Mn}^{\mathrm{III}}$ atoms and also the possibly of weak 
(a)

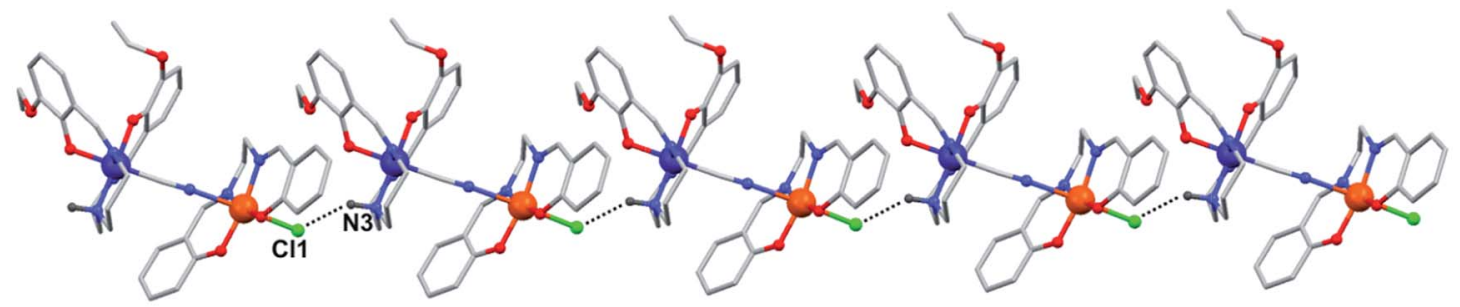

(b)

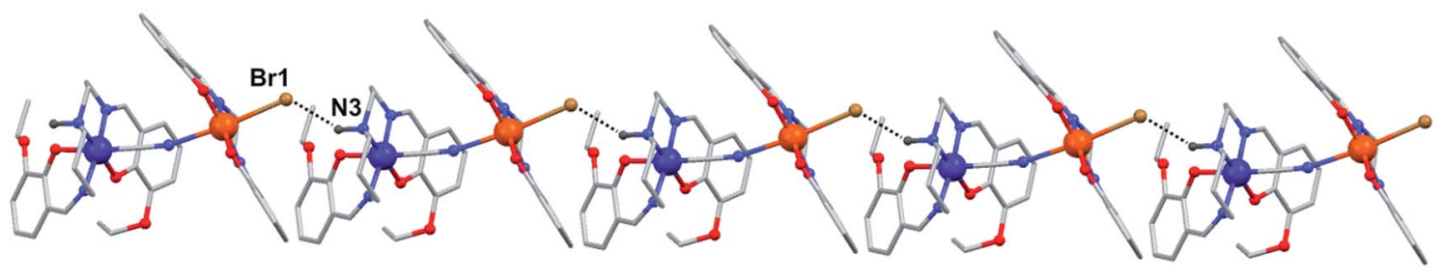

(c)
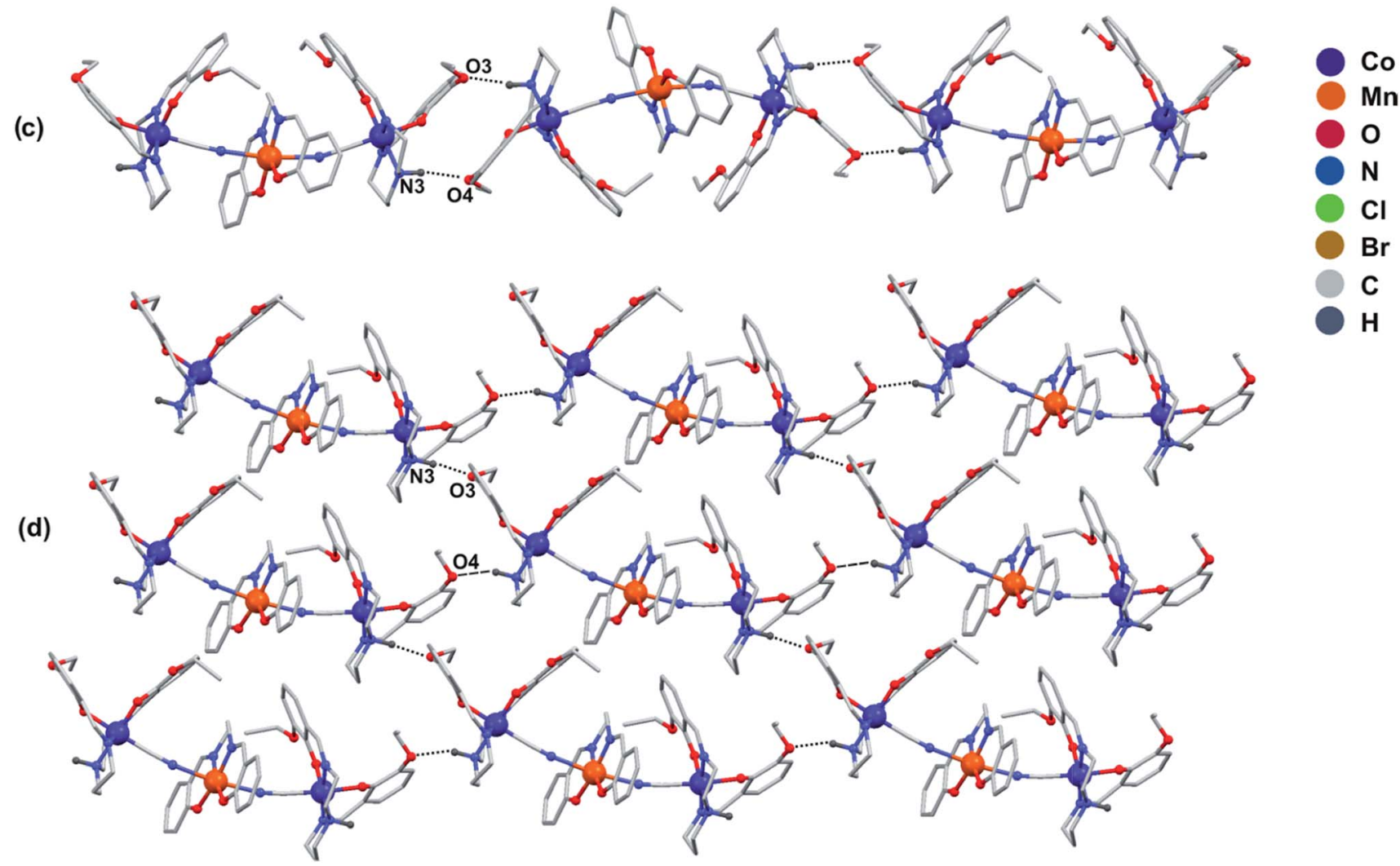

$\mathrm{Br}$

Fig. 2 A perspective view on supramolecular chains held by $\mathrm{N}-\mathrm{H} \cdots \mathrm{Cl}$ hydrogen bonds (dotted lines) in 1 (a) and $\mathrm{N}-\mathrm{H} \cdots \mathrm{Br}$ in 2 (b). A perspective view on supramolecular chains held by $\mathrm{N}-\mathrm{H} \cdots \mathrm{O}$ hydrogen bonds in 3 (c). The donor $\cdots$ acceptor distances for selected non-covalent contacts (in $\AA): d(\mathrm{~N} \cdots \mathrm{Cl})=3.189(3)$ in $1, d(\mathrm{~N} \cdots \mathrm{Br})=3.306(4)$ in $2, d(\mathrm{~N} \cdots \mathrm{O})=3.168(4)$ and $3.307(4)$ in 3 and $3.173(4)$ in 4 (d).

intermolecular interactions. Moreover, the isothermal magnetizations do not saturate to $M_{\mathrm{mol}} / N_{\mathrm{A}} \mu_{\mathrm{B}}=4.0$ at maximum applied field for any of 1-3, which can be also explained by significant zero-field splitting. For that reason, the subsequent spin Hamiltonian, involving the single ion axial $(D)$ and rhombic $(E)$ ZFS parameters, Zeeman term and molecular field correction $z j$, were postulated ${ }^{12}$

$$
\hat{H}=D\left(\hat{S}_{z}^{2}-\hat{S}^{2} / 3\right)+E\left(\hat{S}_{x}^{2}-\hat{S}_{y}^{2}\right)+\mu_{\mathrm{B}} B_{a} g \hat{S}_{a}-z j\left\langle\hat{S}_{a}\right\rangle \hat{S}_{a}
$$

where $a$ defines the orientation of the magnetic field vector in polar coordinates as $B_{a}=B(\sin \theta \cos \varphi, \sin \theta \sin \varphi, \cos \theta)$. The molar magnetization in the $a$-direction of the magnetic field, $M_{a}$, was numerically calculated as

$$
M_{a}=-N_{A} \frac{\sum_{i}\left(\sum_{k} \sum_{l} C_{i k}^{+}\left(\boldsymbol{Z}_{a}\right)_{k l} C_{l i}\right) \exp \left(-\varepsilon_{a, i} / k T\right)}{\sum_{i} \exp \left(-\varepsilon_{a, i} / k T\right)}
$$



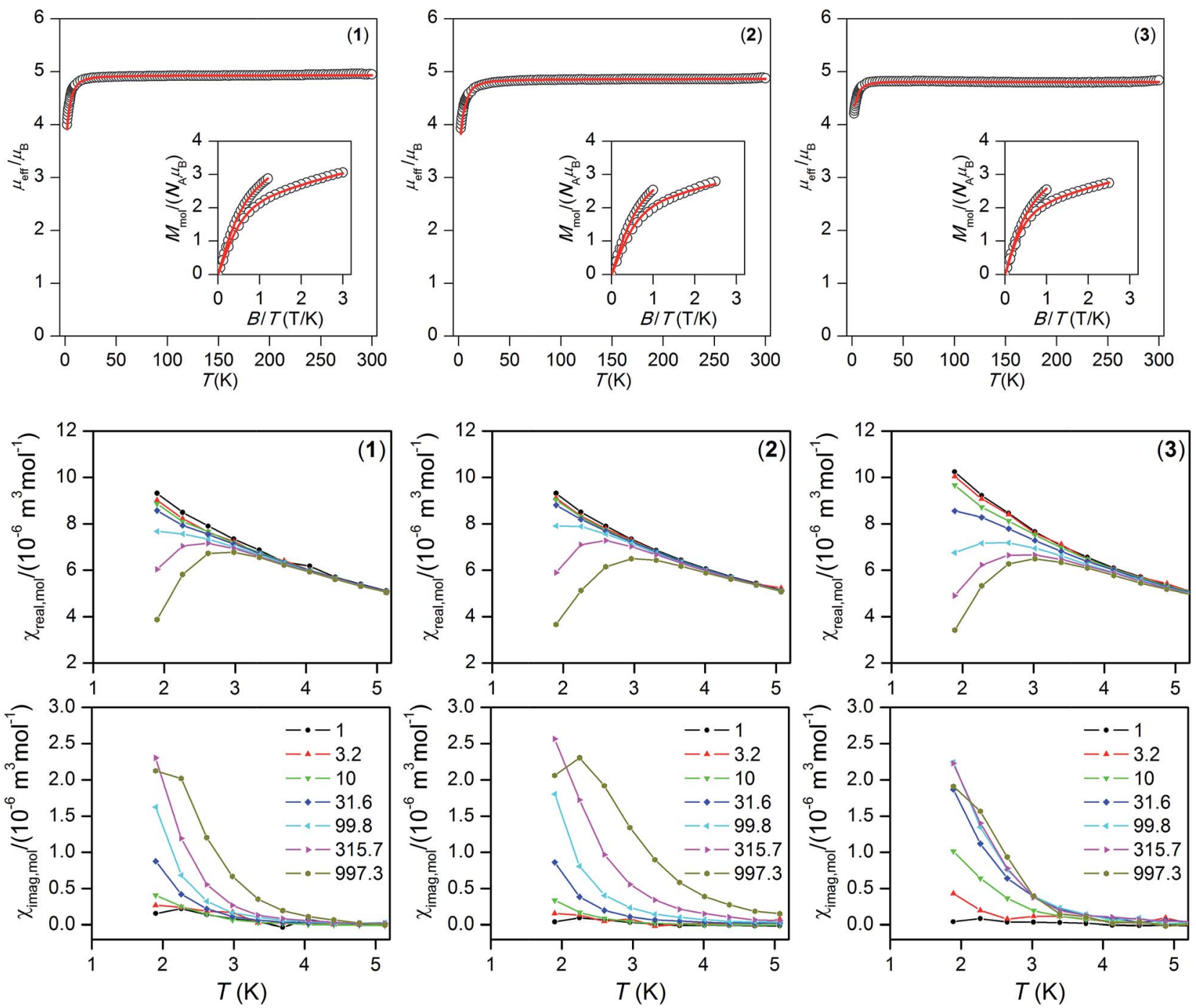

Fig. 3 Top: the temperature dependence of the effective magnetic moment derived from molar magnetization measured at $B=0.1 \mathrm{~T}$ and reduced isothermal magnetizations measured at $T=2$ and $5 \mathrm{~K}$. Empty circles: experimental data. Red full lines: calculated data using eqn (1), with parameters listed in Table 1. Bottom: AC susceptibility data measured at non-zero static magnetic field, $B_{\mathrm{DC}}=0.4 \mathrm{~T}$. Lines serve as guides for the eyes.

where $Z_{a}$ is the matrix element of the Zeeman term for the $a$ direction of the magnetic field and $C$ are the eigenvectors resulting from the diagonalization of the complete spin Hamiltonian matrix. The presence of $z j$ means that the iterative procedure must be applied. The final calculated molar magnetization was calculated as an integral average in order to properly simulate the powder sample signal.

$$
M_{\mathrm{mol}}=1 / 4 \pi \int_{0}^{2 \pi} \int_{0}^{\pi} M_{a} \sin \theta \mathrm{d} \theta \mathrm{d} \varphi
$$

Both, temperature and field dependent magnetic data were fitted simultaneously in order to obtain a consistent set of parameters; however, we found that the fitting procedure was not sensitive enough to the rhombicity of the systems $(E / D$ ratio), and so we fixed $E / D=0$. This is also supported by multiconfigurational complete active space self-consistent field
(CASSCF) calculations, where $E / D$ was found to be less than 0.04 (Table 3). Consequently, the single-ion axial ZFS parameter $D$ was found in the range from -3.9 to $-4.4 \mathrm{~cm}^{-1}$ (Fig. 3). ${ }^{13}$ These values are close to other $\mathrm{Mn}^{\mathrm{III}}$ complexes listed in Table 3 .

\section{Dynamic magnetic properties}

The AC susceptibility data measured in zero static magnetic field showed no out-of-phase susceptibility signal (Fig. S1, ESI $†$ ), but the field dependent measurement at the lowest temperature $(1.9 \mathrm{~K})$ confirmed field-induced slow relaxation of magnetization in 1-3 (Fig. S2 $\dagger$ ). Therefore, the AC susceptibility data were measured at non-zero static magnetic field, $B_{\mathrm{DC}}=0.2$ and $0.4 \mathrm{~T}$, for various frequencies of small AC field as depicted in Fig. 3, and S3 in ESI, $\dagger$ respectively. Clearly, the out-of-phase signal is frequency dependent, but lower temperature would be needed to see maxima on out-of-phase susceptibilities. 
Table 3 Selected parameters derived from analysis of static and dynamic magnetic properties of $\mathrm{Mn}^{\text {III }}$ single-ion magnets ${ }^{a}$

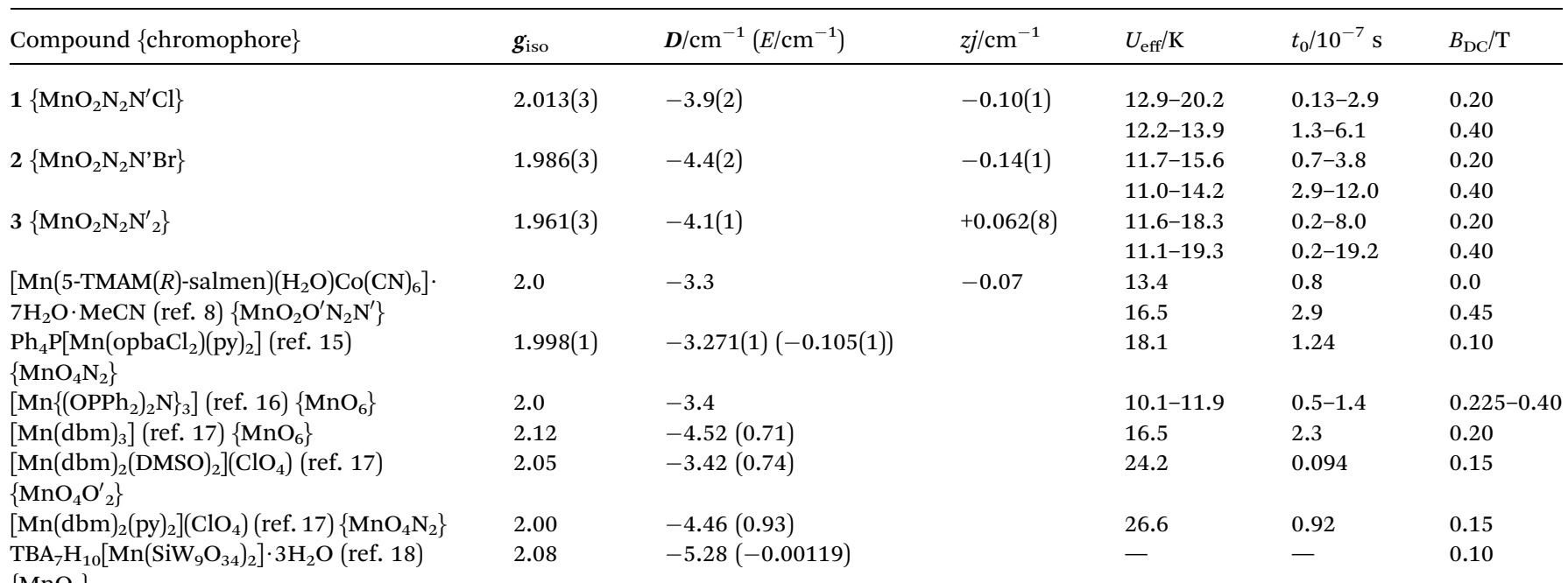
$\left\{\mathrm{MnO}_{6}\right\}$

${ }^{a}$ Ligand abbreviations: 5-TMAM- $(R)$-salmen $=(R)-N, N^{\prime}$-(1-methylethylene)bis(5-trimethylammoniomethylsalicylideneiminate); $\mathrm{H}_{4} \mathrm{OpbaCl}_{2}=N, N^{\prime}-$ 3,4-dichloro-o-phenylenebis(oxamic acid), py $=$ pyridine, $\mathrm{Ph}_{4} \mathrm{P}^{+}=$tetraphenylphosphonium $(1+) ; \operatorname{dbm}=\operatorname{dibenzoylmethanido}(1-)$; $\mathrm{TBA}=$ tetra- $n$ butylammonium(1+); DMSO = dimethyl sulfoxide.

This prevented us from constructing the Argand (Cole-Cole) diagram and analysing the data to obtain information about the spin reversal barrier by a one-component Debye model. Nevertheless, at least the approximate relationship ${ }^{14}$

$$
\ln \left(\chi^{\prime \prime} / \chi^{\prime}\right)=\ln \left(2 \pi f \tau_{0}\right)+U / k T
$$

for the extraction of the relaxation time $\left(\tau_{0}\right)$ and spin reversal barrier $(U)$ was applied to low temperature data and higher applied frequencies as depicted in Fig. S4 in ESI. $\dagger$ In such a way we obtained sets of parameters, which are listed in detail in Table $51 \uparrow$ for both static fields and all the compounds 1-3. Briefly, the spin reversal barriers $U$ were found in the interval from 11 to $20 \mathrm{~K}$ depending on $B_{\mathrm{DC}}$ and selected frequency $f$, which is lower than the theoretically predicted values $(U=4|D|)$ spanning the interval from 22 to $25 \mathrm{~K}$ (Table 3). Such lowering of the spin reversal barrier is usually ascribed to quantum tunnelling caused by the rhombic term.

\section{Theorethical calculations of spin Hamiltonian parameters}

With the aim to support the outcomes of the analysis of magnetic data, multi-reference $a b$ initio calculations based on

Table 4 Spin Hamiltonian parameters of the studied compounds $1-3$ derived from ab initio CASSCF/NEVPT2 calculations ${ }^{a}$

\begin{tabular}{lllll}
\hline & $\boldsymbol{D} / \mathrm{cm}^{-1}$ & $E / D$ & $\boldsymbol{g}_{1}, \boldsymbol{g}_{2}, \boldsymbol{g}_{3}$ & $\boldsymbol{g}_{\text {iso }}$ \\
\hline $\mathbf{1}$ & -3.24 & 0.036 & $1.977,1.994,1.995$ & 1.989 \\
$\mathbf{1}^{\prime}$ & -3.38 & 0.035 & $1.976,1.994,1.995$ & 1.988 \\
$\mathbf{2}$ & -3.03 & 0.025 & $1.978,1.994,1.995$ & 1.989 \\
$\mathbf{2}^{\prime}$ & -3.18 & 0.025 & $1.979,1.994,1.994$ & 1.988 \\
$\mathbf{3}^{\prime}$ & -3.58 & 0.044 & $1.977,1.994,1.995$ & 1.988
\end{tabular}

${ }^{a}$ Molecular fragments: [Co(3EtO-L5)( $\left.\left.\mu-\mathrm{CN}\right) \mathrm{Mn}(\mathrm{L} 4 \mathrm{a}) \mathrm{Cl}\right]$ (1), [Co(3EtO$\mathrm{L} 5)(\mu-\mathrm{CN}) \mathrm{Mn}(\mathrm{L} 4 \mathrm{a}) \mathrm{Br}](2),[(\mathrm{CN}) \mathrm{Mn}(\mathrm{L} 4 \mathrm{a}) \mathrm{Cl}]^{-}\left(1^{\prime}\right)[(\mathrm{CN}) \mathrm{Mn}(\mathrm{L} 4 \mathrm{a}) \mathrm{Br}]^{-}\left(2^{\prime}\right)$ and $\left[(\mathrm{CN})_{2} \mathrm{Mn}(\mathrm{L} 4 \mathrm{a})\right]^{-}\left(3^{\prime}\right)$. state-averaged complete-active-space self-consistent field (SACASSCF) wave functions complemented by $\mathrm{N}$-electron valence second-order perturbation theory (NEVPT2) were done using ORCA software. The active space was set to the metal-based dorbitals, $\operatorname{CAS}(4,5)$. Firstly, the calculations were performed on the molecular geometries of the whole complex units for $[\mathrm{Co}(3 \mathrm{EtO}-\mathrm{L} 5)(\mu-\mathrm{CN}) \mathrm{Mn}(\mathrm{L} 4 \mathrm{a}) \mathrm{Cl}]$ of 1 and [Co(3EtO-L5)( $\mu$-CN) $\mathrm{Mn}(\mathrm{L} 4 \mathrm{a}) \mathrm{Br}]$ of 2 . Due to the fact that such calculations are timeconsuming, especially for compound 3 , which has a larger number of atoms than compounds $\mathbf{1}$ and $\mathbf{2}$, we decided to test the possibility to truncate the molecular geometry of complex compounds 1-3 into geometrical fragments without the diamagnetic $\mathrm{Co}^{\mathrm{III}}$ subunits as $[(\mathrm{CN}) \mathrm{Mn}(\mathrm{L} 4 \mathrm{a}) \mathrm{Cl}]^{-}\left(\mathbf{1}^{\prime}\right),[(\mathrm{CN})$ $\mathrm{Mn}(\mathrm{L} 4 \mathrm{a}) \mathrm{Br}]^{-}\left(2^{\prime}\right)$ and $\left[(\mathrm{CN})_{2} \mathrm{Mn}(\mathrm{L} 4 \mathrm{a})\right]^{-}\left(3^{\prime}\right)$. The achieved parameters of $\boldsymbol{g}$-tensors and $\boldsymbol{D}$-tensors are summarized in Table 4. It is evident that the geometry truncation led only to minor changes in $D$-values, i.e. less than $0.15 \mathrm{~cm}^{-1}$ for $\mathbf{1}$ and $\mathbf{2}$,

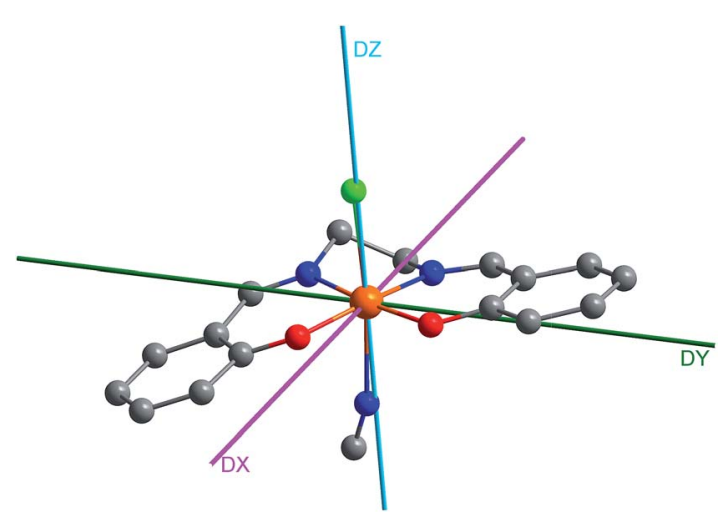

Fig. 4 Molecular structure of $\left[(\mathrm{CN}) \mathrm{Mn}(\mathrm{L} 4 \mathrm{a}) \mathrm{Cl}^{-}\left(1^{\prime}\right)\right.$ overlaid with $D$ tensor axes derived from ab initio calculations. Hydrogen atoms were omitted for clarity. 
and this is usually within the experimental error. The calculated values are in good agreement with the experimentally derived ones, we observed slightly lower calculated $D$-values, which may be attributed to the neglecting of spin-spin contribution to the $\boldsymbol{D}$-tensor. Next, the rhombicity of the studied compounds was found very low, $E / D<0.05$ justifying the neglecting of the $E$-term in fitting the magnetic data. Furthermore, the main axes of the $\boldsymbol{D}$-tensor are visualized in Fig. 4 for the molecular fragment $\mathbf{1}^{\prime}$ showing that the easy axis of magnetization can be identified with the Jahn-Teller axis, hence with the $\mathrm{CN}-\mathrm{Mn}-\mathrm{Cl}$ bonds.

\section{Conclusions}

In this article we reported on the synthesis and properties of new heterobimetalic $\mathrm{Co}^{\mathrm{III}} \cdots \mathrm{Mn}^{\mathrm{III}}$ compounds. Two novel dinuclear, [Co(3EtO-L5)( $\mu-\mathrm{CN}) \mathrm{Mn}(\mathrm{L} 4 \mathrm{a}) \mathrm{Cl}]$ (1) and [Co(3EtO$\mathrm{L5})(\mu-\mathrm{CN}) \mathrm{Mn}(\mathrm{L} 4 \mathrm{a}) \mathrm{Br}](2)$, and two new trinuclear [\{Co(3EtO$\mathrm{L} 5)(\mu-\mathrm{CN})\}_{2}\{\mathrm{Mn}(\mathrm{L} 4 \mathrm{a})] \mathrm{I} \quad(3) \quad$ and $\quad\left[\{\mathrm{Co}(3 \mathrm{EtO}-\mathrm{L} 5)(\mu-\mathrm{CN})\}_{2^{-}}\right.$ $\mathrm{Mn}(\mathrm{L} 4 \mathrm{a})]\left(\mathrm{NO}_{3}\right)$ (4) compounds were prepared. The crystal structures were determined for all four herein presented compounds but magnetic properties were studied only for compounds 1-3 in greater details due to the structural similarity of compounds 3 and 4 . The magnetic data analysis, involving the spin Hamiltonian with the axial zero-field splitting term, revealed a relatively large and negative value of the axial magnetic anisotropy parameter $D\left(\right.$ in $\left.\mathrm{cm}^{-1}\right):-3.9(2)$ in $\mathbf{1}$, $-4.9(2)$ in 2, and $-4.1(1)$ in 3. The experimental study was supported by $a b$ initio calculations at the CASSCF level of theory and the values of $D_{\text {calc }}$, which are in good agreement with the experimentally derived parameters, were obtained. Furthermore, small rhombicity $\left(E_{\text {calc }}\right)$ for compounds 1-3 was proposed: $D_{\text {calc }}\left(E_{\text {calc }} / D_{\text {calc }}\right)=-3.2 \mathrm{~cm}^{-1}(0.04)$ in $1,-3.0 \mathrm{~cm}^{-1}$ (0.03) in 2 and $-3.6 \mathrm{~cm}^{-1}(0.04)$ in 3. In summary, it has been found that the value of the $D$ parameter does not depend neither on the axial length or lowering of the ligand-field strength by the ligand exchange significantly. This can be documented by two contrasting examples. The longest axial length is observed for $2(\mathrm{~N}-\mathrm{Mn}-\mathrm{Br}$ type, $d(\mathrm{~N} \cdots \mathrm{Br})=5.058(4) \AA$, angle $\left.(\mathrm{N}-\mathrm{Mn}-\mathrm{Br})=174.5(1)^{\circ}\right)$ and this compound possesses also the largest negative $D$ value $\left(-4.9 \mathrm{~cm}^{-1}\right)$. The shortest axial length is found in $3(\mathrm{~N}-\mathrm{Mn}-\mathrm{N}$ type, $d(\mathrm{~N} \cdots \mathrm{N})=4.617(5) \AA$, angle $\left.(\mathrm{N}-\mathrm{Mn}-\mathrm{N})=171.3(1)^{\circ}\right)$ but the value of the $D$ parameter $(-4.1$ $\mathrm{cm}^{-1}$ ) does not adopt a value much different from that observed for 2 .

The measurements of dynamic magnetic data confirmed that compounds 1-3 behave as field-induced single-ion magnets. The peak maxima of frequency dependent out-phase susceptibility (in static magnetic field of $0.4 \mathrm{~T}$ ) were in all three cases below the lowest accessible temperature $(1.9 \mathrm{~K})$ and thus, we were not able to construct the Argand (Cole-Cole) diagram. Therefore, we used an approximate relationship for the extraction of the relaxation time $\left(\tau_{0}\right)$ and spin reversal barrier $(U)$ and this was applied to low temperature data and higher applied frequencies and as a result the values of $U_{\text {eff }}$ ranging from 11 to $20 \mathrm{~K}$ and $t_{0}$ from 0.1 to $19 \times 10^{-7} \mathrm{~s}$ were obtained.

\section{Experimental}

\section{Materials}

All the starting chemicals were of analytical reagent grade and were used as received. $\mathrm{CoCl}_{2} \cdot 4 \mathrm{H}_{2} \mathrm{O}, \mathrm{MnCl}_{2} \cdot 4 \mathrm{H}_{2} \mathrm{O}, \mathrm{MnBr}_{2}, \mathrm{MnI}_{2}$, $\mathrm{NaCN}, \mathrm{AgNO}_{3}$, solvents and the organic compounds 2-hydroxybenzaldehyde, 3-ethoxy-2-hydroxybenzaldehyde, ethane-1,2diamine, $N$-(2-aminoethyl)-1,3-propanediamine, and triethylamine $\left(\mathrm{Et}_{3} \mathrm{~N}\right)$ were obtained from commercial sources (SigmaAldrich Co., Acros Organics Co., Lachema Co. and Fluka Co.).

\section{Synthesis of precursor complexes}

The manganese(III) complexes were prepared according to the literature procedures. ${ }^{19}$ From the conductivity measurements it is apparent that iodide anion in $[\mathrm{Mn}(\mathrm{L} 4 \mathrm{a})] \mathrm{I}$ is not coordinated to $\mathrm{Mn}^{\mathrm{III}}$ atom.

[Mn(L4a)Cl]. Yield: 93\% (663 mg), Anal. calcd for $\mathrm{C}_{16} \mathrm{H}_{14}{ }^{-}$ $\mathrm{N}_{2} \mathrm{O}_{2} \mathrm{Cl}_{1} \mathrm{Mn}_{1}$ : C, 53.87; H, 3.95; N, 7.85. Found: C, 53.96; H, 3.74; $\mathrm{N}, 7.65 \% . \Lambda_{\mathrm{M}}$ (in dimethyl formamide, further abbr. as DMF, $\mathrm{S}$ $\left.\mathrm{cm}^{2} \mathrm{~mol}^{-1}\right): 11.7$.

[Mn(L4a)Br]. Yield: $82 \%$ (658 mg), Anal. calcd for $\mathrm{C}_{16} \mathrm{H}_{14}{ }^{-}$ $\mathrm{N}_{2} \mathrm{O}_{2} \mathrm{Br}_{1} \mathrm{Mn}_{1}$ : C, 47.90; H, 3.51; N, 6.98. Found: C, 47.88; H, 3.69; $\mathrm{N}, 6.57 \% . \Lambda_{\mathrm{M}}\left(\mathrm{DMF}, \mathrm{S} \mathrm{cm} \mathrm{mol}^{-1}\right): 15.8$.

[Mn(L4a)]I. Yield: $74 \%$ (663 mg), Anal. calcd for $\mathrm{C}_{16} \mathrm{H}_{14} \mathrm{~N}_{2}$ $\mathrm{O}_{2} \mathrm{I}_{1} \mathrm{Mn}_{1}: \mathrm{C}, 42.88 ; \mathrm{H}, 3.14 ; \mathrm{N}, 6.25$. Found: $\mathrm{C}, 42.58 ; \mathrm{H}, 3.41 ; \mathrm{N}$, 6.44\%. $\Lambda_{\mathrm{M}}\left(\mathrm{DMF}, \mathrm{S} \mathrm{cm} \mathrm{mol}^{-1}\right): 76.8$.

\section{Synthesis of complexes 1, 2, 3 and 4}

Dark crystals of complexes 1-3 were obtained from a methanol solution $(10 \mathrm{~mL})$ of the corresponding precursor complexes $(0.1$ mmol) combined with a methanol/acetonitrile $(10 / 10 \mathrm{~mL})$ solution of $[\mathrm{Co}(3-\mathrm{EtO}-\mathrm{L} 5)(\mathrm{CN})](\mathbf{1})(0.1 \mathrm{mmol})$. The solutions were mixed and the resulting mixture was stirred at room temperature for $1 \mathrm{~h}$. Slow diffusion of diethyl ether into the resulting solution in a closed bottle afforded black single crystals. Black crystals were filtered off, washed twice with cold methanol, diethyl ether and dried in vacuum.

The single crystals of $\mathbf{4}$ were prepared by the method involving $\mathrm{NaF}$ and $\mathrm{AgNO}_{3}$ as described in the Synthesis chapter. In order to prepare a pure phase system the crystals of complex 4 were obtained by a different procedure. A methanol solution $(10 \mathrm{~mL})$ of complex 1 was mixed with a water solution $(5 \mathrm{~mL})$ of $\mathrm{AgNO}_{3}$ (stoichiometric amount). A white powder (AgCl) was filtered off. Black crystals of $\mathbf{4}$ were obtained by slow diffusion of diethyl ether into the mother liquor in a closed bottle after a week.

[Co(3EtO-L5)( $\mu$-CN)Mn(L4a)Cl] (1). Yield: 85\% (73 mg), Anal. calcd for $\mathrm{C}_{40} \mathrm{H}_{43} \mathrm{~N}_{6} \mathrm{O}_{6} \mathrm{Cl}_{1} \mathrm{Co}_{1} \mathrm{Mn}_{1}$ : C, 56.31; H, 5.08; N, 9.85. Found: C, 56.72; H, 5.32; N, 9.71\%. $\Lambda_{\mathrm{M}}\left(\mathrm{DMF}, \mathrm{S} \mathrm{cm}^{2} \mathrm{~mol}^{-1}\right): 8.3$. FT-IR $\left(\mathrm{cm}^{-1}\right): 3428 \mathrm{w} ; 3106 \mathrm{w} \nu(\mathrm{C}-\mathrm{H})_{\mathrm{ar}} ; 2962 \mathrm{w} \nu(\mathrm{C}-\mathrm{H})_{\text {alip }} ; 2925 \mathrm{w}$ $\nu(\mathrm{C}-\mathrm{H})_{\text {alip }} ; 2136 \mathrm{~m} \nu(\mathrm{C} \equiv \mathrm{N}) ; 1633 \mathrm{~s} \nu(\mathrm{C}=\mathrm{N})_{\text {ar }} ; 1600 \mathrm{~s} \nu(\mathrm{C}=\mathrm{N})_{\mathrm{ar}}$; $1538 \mathrm{~m} \nu(\mathrm{C}=\mathrm{C})_{\mathrm{ar}} ; 1467 \mathrm{~m} \nu(\mathrm{C}=\mathrm{C})_{\mathrm{ar}} ; 1437 \mathrm{~m} \nu(\mathrm{C}=\mathrm{C})_{\mathrm{ar}} ; 1385 \mathrm{w}$; $1337 \mathrm{w} ; 1324 \mathrm{w} ; 1300 \mathrm{~m} ; 1240 \mathrm{w} ; 1224 \mathrm{w} ; 1216 \mathrm{w} ; 1172 \mathrm{w} ; 1153 \mathrm{w}$; 1133w; 1089w; 1078w; 1057w; 1036w; 1009w; 900w; 854w; 798w; 764m; 753m; 627w. 
[Co(3EtO-L5)( $\mu$-CN)Mn(L4a)Br] (2). Yield: 77\% (69 mg), Anal. calcd for $\mathrm{C}_{40} \mathrm{H}_{43} \mathrm{~N}_{6} \mathrm{O}_{6} \mathrm{Br}_{1} \mathrm{Co}_{1} \mathrm{Mn}_{1}$ : C, 53.52; $\mathrm{H}, 4.82 ; \mathrm{N}, 9.36$. Found: C, 53.09; H, 4.68; N, 9.55\%. $\Lambda_{\mathrm{M}}\left(\mathrm{DMF}, \mathrm{S} \mathrm{cm} \mathrm{mol}^{-1}\right.$ ): 10.5. FT-IR $\left(\mathrm{cm}^{-1}\right): 3096 \mathrm{w} \nu(\mathrm{C}-\mathrm{H})_{\mathrm{ar}} ; 2960 \mathrm{w} \nu(\mathrm{C}-\mathrm{H})_{\mathrm{alip}} ; 2928 \mathrm{w}$ $\nu(\mathrm{C}-\mathrm{H})_{\text {alip }} ; 2863 \mathrm{w} ; 2139 \mathrm{~m} \nu(\mathrm{C} \equiv \mathrm{N}) ; 1647 \mathrm{w} \nu(\mathrm{C}=\mathrm{N})_{\mathrm{ar}} ; 1622 \mathrm{vs}$ $\nu(\mathrm{C}=\mathrm{N})_{\mathrm{ar}} ; 1598 \mathrm{~m} \nu(\mathrm{C}=\mathrm{C})_{\mathrm{ar}} ; 1539 \mathrm{~m} \nu(\mathrm{C}=\mathrm{C})_{\mathrm{ar}} ; 1466 \mathrm{~m} \nu(\mathrm{C}=\mathrm{C})_{\mathrm{ar}} ;$ $1433 \mathrm{~s} \nu(\mathrm{C}=\mathrm{C})_{\mathrm{ar}} ; 1385 \mathrm{~m} ; 1321 \mathrm{w} ; 1296 \mathrm{~m} ; 1241 \mathrm{w} ; 1213 \mathrm{~m} ; 1150 \mathrm{w}$; $1130 w ; 1108 w ; 1079 w ; 1039 w ; 970 w ; 899 w ; 877 w ; 853 w ; 797 w ;$ 749m; 625w.

[\{Co(3EtO-L5) $\left.(\mu-\mathbf{C N})\}_{2} \mathbf{M n}(\mathbf{L} 4 a)\right] \mathrm{I}$ (3). Yield: 69\% (99 mg), Anal. calcd for $\mathrm{C}_{64} \mathrm{H}_{72} \mathrm{~N}_{10} \mathrm{O}_{10} \mathrm{I}_{1} \mathrm{Co}_{2} \mathrm{Mn}_{1}: \mathrm{C}, 53.34 ; \mathrm{H}, 5.03 ; \mathrm{N}$, 9.71. Found: $\mathrm{C}, 53.48 ; \mathrm{H}, 5.14 ; \mathrm{N}, 9.48 \% . \Lambda_{\mathrm{M}}\left(\mathrm{DMF}, \mathrm{S} \mathrm{cm}{ }^{2}\right.$ $\left.\mathrm{mol}^{-1}\right)$ : 89.2. FT-IR $\left(\mathrm{cm}^{-1}\right)$ : $3052 \mathrm{w} \nu(\mathrm{C}-\mathrm{H})_{\mathrm{ar}} ; 3022 \mathrm{w} \nu(\mathrm{C}-\mathrm{H})_{\mathrm{ar}}$; $2971 \mathrm{w} \nu(\mathrm{C}-\mathrm{H})_{\text {alip }} ; 2936 \mathrm{w} \nu(\mathrm{C}-\mathrm{H})_{\text {alip }} ; 2815 \mathrm{w} ; 2713 \mathrm{w} ; 2137 \mathrm{~m}$ $\nu(\mathrm{C} \equiv \mathrm{N}) ; 2131 \mathrm{~s} \nu(\mathrm{C} \equiv \mathrm{N}) ; 1622 \mathrm{~s} \nu(\mathrm{C}=\mathrm{N})_{\mathrm{ar}} ; 1574 \mathrm{~m} \nu(\mathrm{C}=\mathrm{C})_{\mathrm{ar}}$; $1552 \mathrm{~m} \nu(\mathrm{C}=\mathrm{C})_{\mathrm{ar}} ; 1496 \mathrm{~m} \nu(\mathrm{C}=\mathrm{C})_{\mathrm{ar}} ; 1432 \mathrm{w} ; 1415 \mathrm{w} ; 1396 \mathrm{w}$; $1354 \mathrm{~m} ; 1332 \mathrm{w} ; 1251 \mathrm{~m} ; 1200 \mathrm{w} ; 1174 \mathrm{w} ; 1163 \mathrm{w} ; 1128 \mathrm{w} ; 1085 \mathrm{w}$; 1008w; 970m; 885w; 742w; 738m; 724w; 663w.

[\{Co(3EtO-L5) $\left.(\mu-\mathrm{CN})\}_{2} \mathrm{Mn}(\mathrm{L4a})\right]\left(\mathrm{NO}_{3}\right) \quad$ (4). Yield: $\quad 66 \% \quad(91$ $\mathrm{mg}$ ), Anal. calcd for $\mathrm{C}_{64} \mathrm{H}_{72} \mathrm{~N}_{11} \mathrm{O}_{13} \mathrm{Co}_{2} \mathrm{Mn}_{1}$ : C, $55.85 ; \mathrm{H}, 5.27 ; \mathrm{N}$, 11.19. Found: C, 55.63; H, 5.41; N, 11.33\%. $\Lambda_{\mathrm{M}}$ (DMF, $\mathrm{S} \mathrm{cm}{ }^{2}$ $\left.\mathrm{mol}^{-1}\right): 71.5$. FT-IR $\left(\mathrm{cm}^{-1}\right): 3462 \mathrm{w} ; 3215 \mathrm{w} \nu(\mathrm{C}-\mathrm{H})_{\mathrm{ar}} ; 3165 \mathrm{w} \nu(\mathrm{C}-$ $\mathrm{H})_{\mathrm{ar}} ; 2950 \mathrm{w} \nu(\mathrm{C}-\mathrm{H})_{\mathrm{alip}} ; 2912 \mathrm{w} \nu(\mathrm{C}-\mathrm{H})_{\mathrm{alip}} ; 2134 \mathrm{~m} \nu(\mathrm{C} \equiv \mathrm{N}) ; 1621 \mathrm{~s}$ $\nu(\mathrm{C}=\mathrm{N})_{\mathrm{ar}} ; 1606 \mathrm{~s} \nu(\mathrm{C}=\mathrm{N})_{\mathrm{ar}} ; 1572 \mathrm{~m} \nu(\mathrm{C}=\mathrm{C})_{\mathrm{ar}} ; 1493 \mathrm{~m} \nu(\mathrm{C}=\mathrm{C})_{\mathrm{ar}}$; $1467 \mathrm{~m} \nu(\mathrm{C}=\mathrm{C})_{\mathrm{ar}} ; 1442 \mathrm{~m} \nu(\mathrm{C}=\mathrm{C})_{\mathrm{ar}} ; 1372 \mathrm{w} ; 1331 \mathrm{w} ; 1316 \mathrm{w}$; $1313 \mathrm{~m} ; 1253 \mathrm{w} ; 1238 \mathrm{w} ; 1165 \mathrm{w} ; 1149 \mathrm{w} ; 1137 \mathrm{w} ; 1096 \mathrm{w} ; 1082 \mathrm{w} ;$ 1063w; 1047w; 1014w; 954w; 872w; 799w; 751m; 744m.

\section{General methods}

Elemental analysis (CHN) was performed on a FLASH $2000 \mathrm{CHN}$ Analyser (ThermoFisher Scientific). Infrared spectra of the complexes were recorded on a ThermoNicolet NEXUS 670 FT-IR spectrometer using the ATR technique on a diamond plate in the range $600-4000 \mathrm{~cm}^{-1}$. The reported FT-IR intensities were defined as $\mathrm{w}=$ weak, $\mathrm{m}=$ medium, $\mathrm{s}=$ strong, and $\mathrm{vs}=$ very strong. The magnetic data were measured on powdered samples pressed into pellets using a MPMS XL-7 Quantum Design SQUID magnetometer. The experimental data were corrected for the diamagnetism of the constituent atoms by using Pascal's constants.

\section{Single-crystal X-ray analysis details}

X-ray measurements on the selected crystals of $1,2,3$ and 4 were performed on an Oxford Diffraction Xcalibur ${ }^{\mathrm{TM}^{2}}$ equipped with a Sapphire2 CCD detector using Mo-K $\alpha$ radiation at $100 \mathrm{~K}$. The CrysAlis program package (version 1.171.33.52, Oxford Diffraction) was used for data collection and reduction. ${ }^{20}$ The molecular structures were solved by direct methods SHELX-2014 and all non-hydrogen atoms were refined anisotropically on $F^{2}$ using full-matrix least-squares procedure SHELXS-2014. ${ }^{21}$ All the hydrogen atoms were found in differential Fourier maps and their parameters were refined using a riding model with $U_{\text {iso }}(\mathrm{H})$ $=1.2\left(\mathrm{CH}, \mathrm{CH}_{2}, \mathrm{OH}\right)$ or $1.5\left(\mathrm{CH}_{3}\right) U_{\text {eq }}$. Non-routine aspects of the structure refinement are as follows: in 3, two ethoxy groups are disordered over two positions; in $\mathbf{4}$, the electron density from heavily disordered nitrate anion was removed by SQUEEZE procedure. $^{22}$

\section{Theoretical methods}

All theoretical calculations were performed with an ORCA 3.0 computational package. ${ }^{23}$ All calculations employed the chainof-spheres (RIJCOSX) approximation to exact exchange. ${ }^{24}$ The polarized triple- $\zeta$-quality basis set def2-TZVP(-f) were used for all atoms except for carbon and hydrogen, for which the def2SVP basis set was chosen. ${ }^{25}$ The ZFS and $\boldsymbol{g}$ tensors were calculated by using self-consistent field (SA-CASSCF) wave functions $^{26}$ complemented by $\mathrm{N}$-electron valence second order perturbation theory (NEVPT2). ${ }^{27}$ The active space of the CASSCF calculation was set to five d-orbitals of $\mathrm{Mn}^{\mathrm{III}}(\mathrm{CAS}(4,5))$. The state-averaged approach was used, in which all 5 quintet, 45 triplet and 50 singlet states were equally weighted. The ZFS parameters, based on dominant spin-orbit coupling contributions from excited states, were calculated through quasidegenerate perturbation theory (QDPT), ${ }^{28}$ in which approximations to the Breit-Pauli form of the spin-orbit coupling operator (SOMF approximation) ${ }^{29}$ and the effective Hamiltonian theory ${ }^{30}$ were utilized. The energies of calculated excited states and their contributions to the $\boldsymbol{D}$-tensors are listed in Tables S1 and S2 (ESI†).

\section{Acknowledgements}

We acknowledge the financial support from the National Programme of Sustainability I (LO1305) of the Ministry of Education, Youth and Sports of the Czech Republic.

\section{Notes and references}

1 (a) D. Gatteschi, R. Sessoli, and J. Villain, Molecular Nanomagnets, Oxford University Press, New York, 2006; $(b)$ M. Ganzhorn and W. Wernsdorfer, in Molecular Magnets, ed. J. Bartolomé, F. Luis and J. F. Fernández, Springer Berlin Heidelberg, 2014, pp. 319-364.

2 R. Herchel, L. Váhovská, I. Potočňák and Z. Trávníček, Inorg. Chem., 2014, 53, 5896-5898.

3 H. Miyasaka, A. Saitoh and S. Abe, Coord. Chem. Rev., 2007, 251, 2622-2664.

4 R. Boča, Coord. Chem. Rev., 2004, 248, 757-815.

5 (a) J. Dreiser, A. Schnegg, K. Holldack, K. S. Pedersen, M. Schau-Magnussen, J. Nehrkorn, P. Tregenna-Piggott, H. Mutka, H. Weihe, J. Bendix and O. Waldmann, Chem.Eur. J., 2011, 17, 7492-7498; (b) K. S. Pederson, J. Dreiser, J. Nehrkorn, M. Gysler, M. Schau-Magnussen, A. Schnegg, K. Holldack, R. Bittl, S. Piligkos, H. Weihe, P. TregennaPiggott, O. Waldmann and J. Bendix, Chem. Commun., 2011, 47, 6918-6920.

6 (a) R. Ababei, Y. Li, O. Roubeau, M. Kalisz, N. Bréfuel, C. Coulon, E. Harté, X. Liu, C. Mathoniére and R. Clérac, New J. Chem., 2009, 33, 1237-1248; (b) J. H. Yoon, J. H. Lim, H. C. Kim and C. S. Hong, Inorg. Chem., 2006, 45, 9613-9615; (c) T. M. Ross, S. M. Neville, D. S. Innes, 
D. R. Turner, B. Moubaraki and K. S. Murray, Dalton Trans., 2010, 39, 149-159; (d) T. Šilha, I. Nemec, R. Herchel and Z. Trávníček, CrystEngComm, 2015, 15, 5351-5358.

7 (a) J. Dreiser, K. S. Pedersen, A. Schnegg, K. Holldack, J. Nehrkorn, M. Sigrist, P. Tregenna-Piggott, H. Mutka, H. Weihe, V. S. Mironov, J. Bendix and O. Waldmann, Chem.-Eur. J., 2013, 19, 3693-3701; (b) K. S. Pedersen, M. Schau-Magnussen, J. Bendix, H. Weihe, A. V. Palii, S. I. Klokishner, S. Ostrovsky, O. S. Reu, H. Mutka and P. L. W. Tregenna-Piggott, Chem.-Eur. J., 2010, 16, 1345813464.

8 R. Ishikawa, R. Miyamoto, H. Nojiri, B. K. Breedlove and M. Yamashita, Inorg. Chem., 2013, 52, 8300-8302.

9 I. Nemec, P. Zoufalý, R. Herchel and Z. Trávníček, Inorg. Chem. Commun., 2013, 35, 50-53.

10 T. Birk, K. S. Pedersen, S. Piligkos, C. A. Thuesen, H. Weihe and J. Bendix, Inorg. Chem., 2011, 50, 5312-5314.

11 J. Bernstein, R. E. Davis, L. Shimoni and N. L. Chang, Angew. Chem., Int. Ed. Engl., 1995, 34, 1555-1573.

12 R. Boča, A Handbook of Magnetochemical Formulae, Elsevier, Amsterdam, 2012.

13 The standard deviations were calculated as $\sigma_{i}=\left(P_{i i}{ }^{-1} \cdot S /(N-\right.$ $k))^{-1 / 2}$, where $P_{i i}=\sum\left(\delta \mu_{n} / \delta a_{i} \cdot \delta \mu_{n} / \delta a_{j}\right)$ and $S=\sum\left(\mu_{n}-\right.$ $\left.\mu_{n}^{\exp }\right)^{2}$ with $n=1$ to $N ; a_{i}$ and $a_{j}$ are fitted parameters, $N$ is number of experimental points (sum of temperature and field dependent data), $\mu_{n}$ and $\mu_{n}^{\exp }$ are the calculated and experimental effective magnetic moments for given temperature and magnetic field. The $\sigma_{i}$ was then multiplied by Student's $t_{95 \%}$ to provide confidence limits with $95 \%$ probabilities listed in text.

14 J. Bartolomé, G. Filoti, V. Kuncser, G. Schinteie, V. Mereacre, C. E. Anson, A. K. Powell, D. Prodius and C. Turta, Phys. Rev. B: Condens. Matter Mater. Phys., 2009, 80, 014430.

15 J. Vallejo, A. Pascual-Álvarez, J. Cano, I. Castro, M. Julve, F. Lloret, J. Krzystek, G. De Munno, D. Armentano, W. Wernsdorfer, R. Ruiz-García and E. Pardo, Angew. Chem., Int. Ed., 2013, 52, 14075-14079.

16 A. Grigoropoulos, M. Pissas, P. Papatolis, V. Psycharis, P. Kyritsis and Y. Sanakis, Inorg. Chem., 2013, 52, 1286912871.
17 L. Chen, J. Wang, Y.-Z. Liu, Y. Song, X.-T. Chen, Y.-Q. Zhang and Z.-L. Xue, Eur. J. Inorg. Chem., 2015, 271-278.

18 R. Sato, K. Suzuki, T. Minato, M. Shinoe, K. Yamaguchi and N. Mizuno, Chem. Commun., 2015, 51, 4081-4084.

19 (a) D. J. Gravert and J. H. Griffin, Inorg. Chem., 1996, 35, 4837-4847; (b) Y. Ciringh, S. W. Gordon-Wylie, R. E. Norman, G. R. Clark, S. T. Weintraub and C. P. Horwitz, Inorg. Chem., 1997, 36, 4968-4982.

20 CrysAlis CCD and CrysAlis RED, Version 1.171.33.52, Oxford Diffraction Ltd, England, 2009.

21 G. M. Sheldrick, Acta Crystallogr., Sect. C: Struct. Chem., 2015, 71(1), 3-8.

22 A. L. Spek, J. Appl. Crystallogr., 2003, 36, 7.

23 F. Neese, Wiley Interdiscip. Rev.: Comput. Mol. Sci., 2012, 2, 73-78.

24 F. Neese, F. Wennmohs, A. Hansen and U. Becker, Chem. Phys., 2009, 356, 98-109.

25 (a) A. Schaefer, H. Horn and R. Ahlrichs, J. Chem. Phys., 1992, 97, 2571-2577; (b) F. Weigend and R. Ahlrichs, Phys. Chem. Chem. Phys., 2005, 7, 3297-3305; (c) A. Schaefer, C. Huber and R. Ahlrichs, J. Chem. Phys., 1994, 100, 5829-5835.

26 P. A. Malmqvist and B. O. Roos, Chem. Phys. Lett., 1989, 155, 189-194.

27 (a) C. Angeli, R. Cimiraglia, S. Evangelisti, T. Leininger and J. P. Malrieu, J. Chem. Phys., 2001, 114, 10252-10264; (b) C. Angeli, R. Cimiraglia and J. P. Malrieu, Chem. Phys. Lett., 2001, 350, 297-305; (c) C. Angeli, R. Cimiraglia and J. P. Malrieu, J. Chem. Phys., 2002, 117, 9138-9153; (d) C. Angeli, S. Borini, M. Cestari and R. Cimiraglia, J. Chem. Phys., 2004, 121, 4043-4049; (e) C. Angeli, B. Bories, A. Cavallini and R. Cimiraglia, J. Chem. Phys., 2006, 124, 054108.

28 D. Ganyushin and F. Neese, J. Chem. Phys., 2006, 125, 024103.

29 F. Neese, J. Chem. Phys., 2005, $122,034107$.

30 R. Maurice, R. Bastardis, C. de Graaf, N. Suaud, T. Mallah and N. Guihéry, J. Chem. Theory Comput., 2009, 5, 2977-2984. 